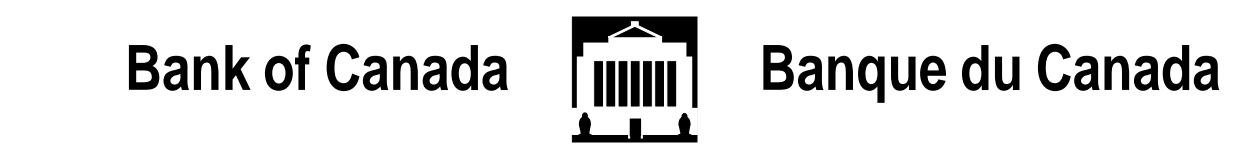

Working Paper 2002-40 / Document de travail 2002-40

\title{
Inflation Changes, Yield Spreads, and Threshold Effects
}

by

Greg Tkacz 
ISSN 1192-5434

Printed in Canada on recycled paper 
Bank of Canada Working Paper 2002-40

December 2002

\title{
Inflation Changes, Yield Spreads, and Threshold Effects
}

\author{
by \\ Greg Tkacz \\ Monetary and Financial Analysis Department \\ Bank of Canada \\ Ottawa, Ontario, Canada K1A 0G9 \\ gtkacz@bankofcanada.ca
}

The views expressed in this paper are those of the author.

No responsibility for them should be attributed to the Bank of Canada. 



\section{Contents}

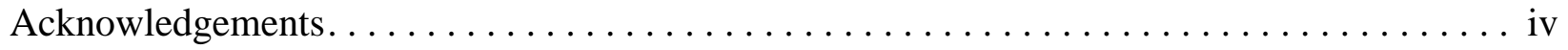

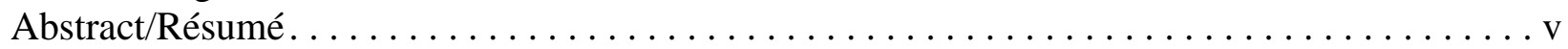

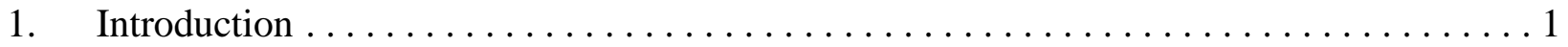

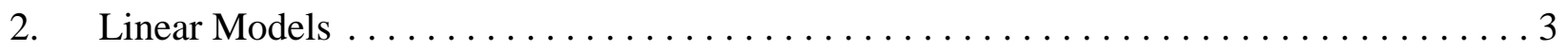

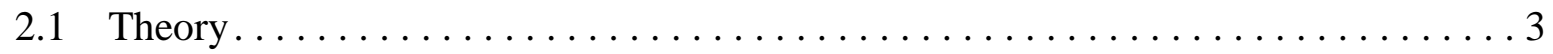

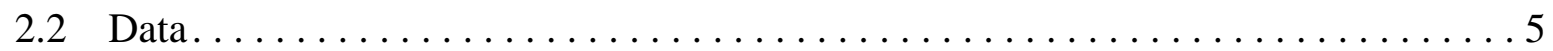

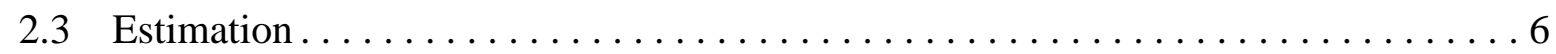

3. Threshold Models $\ldots \ldots \ldots \ldots \ldots \ldots \ldots \ldots \ldots \ldots \ldots \ldots \ldots \ldots \ldots \ldots$

3.1 Motivation. ..........................

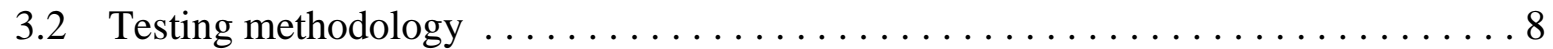

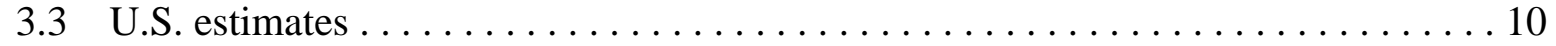

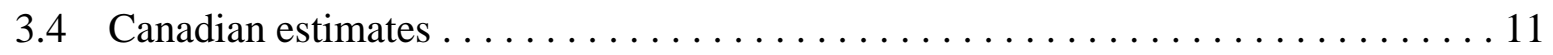

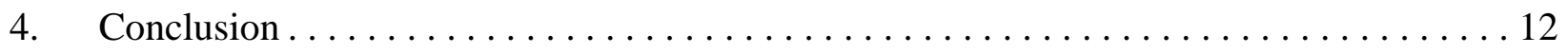

References...................................... 14

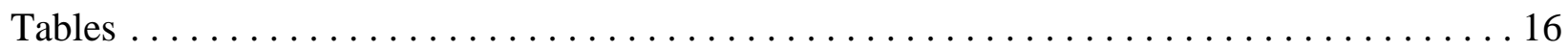




\section{Acknowledgements}

Financial assistance from the McGill Institute for the Study of Canada and the Fonds pour la Formation de chercheurs et l'aide à la recherche (Québec) is gratefully acknowledged for the initial stages of this research. I thank John W. Galbraith, Victoria Zinde-Walsh, Charles Freedman, Jean-Paul Lam, Mingwei Yuan, two anonymous referees, and seminar participants at the Bank of Canada, McGill University, and the annual meetings of the Canadian Economics Association for several useful comments. 


\begin{abstract}
Using interest rate yield spreads to explain changes in inflation, we investigate whether such relationships can be modelled using two-regime threshold models. Implementing a robust test to detect evidence of a threshold, we find that the hypothesis of linearity is generally rejected. For the United States, we find that the inflation-spread relationship at most horizons is more pronounced when the yield curve is inverted, which is usually associated with periods of tight monetary policy. This implies that monetary policy may have an asymmetric effect on inflation. Curiously, the pattern of asymmetry in Canada appears to operate in the opposite direction, with expansionary policies having a relatively greater impact on inflation than tighter policies.

JEL classification: E31, C51

Bank classification: Inflation and prices; Interest rates
\end{abstract}

\title{
Résumé
}

Dans ce document de travail, l'auteur cherche à déterminer, à l'aide de modèles à seuil à deux régimes, s'il est possible de formaliser une relation liant les variations de l'inflation aux écarts de taux de rendement. L'application d'un test robuste pour détecter l'existence d'un seuil entraîne généralement le rejet de l'hypothèse de linéarité. L'auteur constate qu'à la plupart des horizons, la relation entre les écarts de taux de rendement et les variations de l'inflation aux États-Unis est plus prononcée lorsqu'il y a inversion de la courbe de rendement, phénomène que l'on observe habituellement quand la politique monétaire est restrictive. Ces résultats impliquent de possibles effets asymétriques de la politique monétaire sur l'inflation. Curieusement, l'asymétrie semble agir en sens opposé au Canada, où une politique monétaire expansionniste a une incidence relativement plus forte sur l'inflation qu'une politique restrictive.

Classification JEL : E31, C51

Classification de la Banque : Inflation et prix; Taux d'intérêt 



\section{Introduction}

In this paper, we investigate whether threshold effects exist in the relationship between inflation changes and interest rate yield spreads in the United States and Canada, using the technique developed by Hansen (1996) to test for a threshold whose location is unknown a priori. Testing for threshold effects allows us to gauge whether this relationship is more pronounced for certain levels of the interest rate yield spread. Through the introduction of a threshold variable, we can capture potential non-linearities in the relationship within a tractable and intuitively appealing parametric model.

Our interest in non-linearities in general, and in threshold models in particular, is motivated by two factors. First, this work extends and complements the leading-indicator literature of the interest rate yield spread by Mishkin (1990a,b, 1991), Frankel and Lown (1994), and Day and Lange (1997). These authors generally find, within a linear framework, that the term structure of interest rates at longer horizons contains useful information about inflation changes. Detection of significant non-linearities, however, can potentially improve the forecasts of future directions of inflation extracted from the term structure of interest rates, because linear models can simply be viewed as constrained non-linear models. This paper therefore provides some preliminary evidence on whether non-linearities are likely to be of value in extracting inflation information from interest rates.

Second, it has been noted by Laurent (1988, 1989), Bernanke and Blinder (1992), Johnson and Keleher (1996), Blinder (1998), and others that the difference between long-term and short-term interest rates can indicate a monetary policy stance: monetary policy can readily influence shortterm rates, whereas long-term rates are generally market-driven and do not react hastily to everyday policy actions. Furthermore, the long-term rate can act as a proxy for the equilibrium short-term rate, a Wicksellian natural rate of sorts, so that the difference between a long-term and short-term rate can be viewed as a measure of the relative tightness of policy. Some of the yield spreads examined in this paper can be thought to capture the effects of monetary policy, so our results can be compared with other empirical studies on the asymmetric effects of monetary policy, such as by Morgan (1993), Rhee and Rich (1995), Karras (1996) and Karras and Stokes (1999). These authors find that expansionary monetary policy, measured using either money or interest rates as the policy variable, generally has a weaker impact on output growth than a contractionary policy.

The idea of asymmetries in monetary policy was most clearly explained by Friedman (1968), who stated that monetary policy was akin to pushing on a string when expansionary, and pulling on it 
when restrictive. Firms and consumers have an incentive to reduce their investments and consumption when interest rates rise, since projects may no longer be profitable nor goods affordable. When interest rates fall, however, there is no guarantee that firms will immediately increase their investments, because projects that were initially profitable remain profitable, and substantial time may be required to develop and implement new projects that can take advantage of the lower interest rate. If there is a link between real economic activity and the rate of inflation through a Phillips curve, and if asymmetries exist in the effects of monetary policy on the economy, then by Friedman's argument we would expect inflation to be less responsive to expansionary policy than to contractionary policy.

A threshold model lends itself nicely to the detection of asymmetries, such as those proposed in the foregoing description of the effects of monetary policy. The magnitude of the asymmetry can be readily interpreted within the parametric threshold model, because the parameters vary discretely according to the level of the yield spread. More elaborate non-linear models, such as the non-parametric kernel regressions or neural networks used in Tkacz (2000), can capture more subtle non-linearities, but lack the intuitive parametric interpretation of the threshold model.

Our work differs from previous studies in three ways. First, instead of money, we use interest rate yield spreads to measure the effects of policy, because Blinder (1998), among others, emphasizes that policy is conducted through the control of short-term interest rates, not the money stock. Second, we do not restrict our threshold at a zero value of the yield spread, which would be considered the neutral policy setting. Earlier studies usually tested for asymmetry in tight or loose regimes, ignoring potential sources of asymmetry at different values of the policy variable. We consider a more general test that searches over a wide range of possible threshold values, maximizing the likelihood of uncovering any asymmetries, should they exist. Our definition of asymmetry is therefore one in which the relationship between the yield spread and dependent variable is allowed to vary over any value of the spread. Third, we test for threshold effects between interest rate yield spreads and inflation changes, not the rate of output growth. In a related study, Galbraith and Tkacz (2000) detect asymmetries between the yield spread and output growth in the United States and Canada; the current paper extends those results to inflation, a variable that is closely monitored by policy-makers. Thus, should a significant threshold be located, monetary policy would be said to have an asymmetric effect on inflation changes, differing when the yield spread is above and below its threshold value.

Using the yields on securities with maturities ranging from three months to 10 years, we are able to construct 15 different long-minus-short yield spreads for the United States, and 10 for Canada. The indicator properties of each of these spreads for changes in future CPI inflation is considered, 
and, consistent with Mishkin (1990a,b), we find that spreads that jointly incorporate information from both the short and long ends of the interest rate yield curve contain the most explanatory power for future inflation. In the United States, for yield spreads that can be influenced to some degree by monetary policy, we find that significant thresholds emerge when the yield curve is relatively flat or inverted; namely, during periods of monetary tightening. Below these thresholds, the effect of the yield spread on inflation changes is more pronounced than when it is above. This indicates that substantial monetary tightening is likely required to induce the type of asymmetry described by Friedman (1968).

The pattern of asymmetry detected in Canadian data differs from that detected in U.S. data. We find that, in Canada, the yield spread has a greater impact on inflation when it is above the estimated threshold, indicating that expansionary monetary policies have a relatively greater impact on inflation than contractionary monetary policies.

In section 2, we describe the framework used to analyze the relationship between inflation changes and interest rate yield spreads. The data used in this study, and the estimation results of some simple linear models, are also described. Section 3 implements the tests for threshold effects and describes the findings. Section 4 concludes.

\section{Linear Models}

\subsection{Theory}

In general, authors have found that interest rate yield spreads are significant predictors of inflation changes, both for the United States and other countries (Mishkin 1990b, 1991). However, results seem to be dependent upon the area of the yield curve under consideration: interest rate spreads on securities at the short end of the yield curve appear to contain less information than those differentials that utilize long-term rates (Mishkin 1990a). In this section, we briefly describe Mishkin's model, which will be used as the basis of our threshold tests.

We begin by defining the annualized $m$-period inflation rate, $\pi_{t}^{m}$, as $\pi_{t}^{m}=\log \left(P_{t+m} / P_{t}\right) \times 100 \times k / m$, where $k$ is set to 12 , which denotes the number of observations available each year, and $m$ takes the value 3 (three months), 6 (six months), 12 (one year), 24 (two years), 60 (five years), or 120 (10 years). As a result, the inflation rate is expressed in percentage terms. We then note that the $m$-period real interest rate, $r_{t}^{m}$, must satisfy the condition $\left(1+r_{t}^{m}\right)=\left(1+R_{t}^{m}\right) /\left(1+\pi_{t}^{m}\right)$, where $R_{t}^{m}$ is the $m$-period nominal interest rate. Solving for the nominal interest rate, we get 


$$
R_{t}^{m}=r_{t}^{m}+\pi_{t}^{m}+r_{t}^{m} \pi_{t}^{m}
$$

Since the last term in this expression is negligible for small values of $r_{t}^{m}$ and $\pi_{t}^{m}$, it is usually dropped for simplicity. Solving for the inflation rate, we therefore get

$$
\pi_{t}^{m}=R_{t}^{m}-r_{t}^{m}
$$

Equation (2) states that the ex post $m$-period inflation rate is equal to the $m$-period nominal interest rate less the ex post $m$-period real interest rate. Taking an expectations operator through (2), we can derive an expression for the ex ante inflation rate:

$$
E_{t} \pi_{t}^{m}=R_{t}^{m}-E_{t} r_{t}^{m}
$$

This relationship is the familiar Fisher equation; thus, the ex ante $m$-period inflation rate is equal to the $m$-period nominal interest rate, less the ex ante $m$-period real interest rate. We know also that the ex post inflation rate is equal to the ex ante inflation rate and an inflation-forecast error term:

$$
\pi_{t}^{m}=E_{t} \pi_{t}^{m}+\varepsilon_{t}^{m}
$$

Substituting (3) into (4), we get

$$
\pi_{t}^{m}=R_{t}^{m}-E_{t} r_{t}^{m}+\varepsilon_{t}^{m}
$$

which states that the ex post $m$-period inflation rate is equal to the $m$-period nominal interest rate less the ex ante $m$-period real interest rate and an inflation-forecast error. A similar equation can be derived for the $n$-period ex post inflation rate, where $n<m$ :

$$
\pi_{t}^{n}=R_{t}^{n}-E_{t} r_{t}^{n}+\varepsilon_{t}^{n}
$$

Subtracting (6) from (5), we get

$$
\pi_{t}^{m}-\pi_{t}^{n}=\left(R_{t}^{m}-R_{t}^{n}\right)-\left(E_{t} r_{t}^{m}-E_{t} r_{t}^{n}\right)+\left(\varepsilon_{t}^{m}-\varepsilon_{t}^{n}\right)
$$

Let us now decompose the ex ante real rate into the mean of the ex ante real rate over the sample period and deviation from that mean: 


$$
\begin{gathered}
E_{t} r_{t}^{m}=\bar{r}^{m}+\left(E_{t} r_{t}^{m}-\bar{r}^{m}\right)=\bar{r}^{m}+u_{t}^{m}, \\
E_{t} r_{t}^{n}=\bar{r}^{n}+\left(E_{t} r_{t}^{n}-\bar{r}^{n}\right)=\bar{r}^{n}+u_{t}^{n} .
\end{gathered}
$$

Inserting (8) and (9) into (7), we get

$$
\pi_{t}^{m}-\pi_{t}^{n}=\left(R_{t}^{m}-R_{t}^{n}\right)-\left(\bar{r}^{m}-\bar{r}^{n}\right)+\left(\varepsilon_{t}^{m}-\varepsilon_{t}^{n}\right)-\left(u_{t}^{m}-u_{t}^{n}\right) .
$$

By assuming that the difference between the means of the ex ante real interest rates does not change, and by combining all the error terms, we get the following inflation change equation:

$$
\pi_{t}^{m}-\pi_{t}^{n}=\alpha_{m, n}+\beta_{m, n}\left(R_{t}^{m}-R_{t}^{n}\right)+\eta_{t}^{m, n},
$$

where $\alpha_{m, n}$ equals zero and $\beta_{m, n}$ equals one, under the assumptions that the means of the ex ante real interest rates at horizons $m$ and $n$ are equal and that expectations are rational. If these assumptions do not hold, then the postulated values may, of course, differ. Equation (11) therefore represents the model under the null hypothesis in the threshold tests that follow. As the long-short yield spread widens by 100 basis points, we expect the difference between the $m$ - and $n$-period inflation rates to increase by $\beta_{m, n}$ percentage points. In other words, if a widening of the yield spread is to some extent representative of an expansionary monetary policy, then we expect inflation to accelerate in the long run.

\subsection{Data}

We obtained our interest rate data for the United States from Duffee (2002). It spans the period January 1952 to December 1998 and consists of constant-maturity zero-coupon yields at maturities of three, six, and 12 months, and two, five, and 10 years. This data set comprises the McCulloch and Kwon (1993) term structure data up to 1991, extended to 1998 using the techniques described by Bliss (1997). The use of zero-coupon yields makes our parameter estimates comparable to the studies by Mishkin. The dependent variable consists of changes in CPI inflation. ${ }^{1}$

For Canada, we use the par-value bond rates first utilized by Day and Lange (1997), in addition to a 3-month treasury bill rate. Owing to the existence of a thin treasury bill market early in the

1. The interest rate data was downloaded from Gregory Duffee's homepage (http:// faculty.haas.berkeley.edu/duffee/), and the CPI series was obtained from the FRED database at the Federal Reserve Bank of St. Louis (http://research.stlouisfed.org/fred/). 
sample, we do not use 6-month treasury bill rates for Canada because of several missing observations in the series. Owing to data availability, the Canadian sample begins in January 1972 and ends in June 2002. As with the United States, we use changes in total CPI inflation as our dependent variable.

Because the threshold test we perform requires stationary regressors, we need to first test for the presence of unit roots in the data. Performing both augmented Dickey-Fuller and Phillips-Perron tests, we find that all the interest rate spreads are stationary at the usual significance levels. For the inflation changes, we find that unit roots may be present between inflation changes at the longest horizons, namely between 10-year and 3- and 5-year inflation rates. ${ }^{2}$ Upon computing the modified Rescaled Range statistic of Lo (1991), however, we find that these series are most likely stationary in the very long run, which is the likely cause of the non-rejection of the unit root tests, since these tests have low power under fractionally integrated alternatives, as Diebold and Rudebusch (1991) demonstrate. ${ }^{3}$

\subsection{Estimation}

The estimated parameters of (11) for different values of $m$ and $n$ are given in Table 1 for the United States and in Table 2 for Canada. Since the observations are monthly, there is a moving average (MA) term of order ( $m$-1) built into our data. In estimating (11) using least squares, we would expect our residuals to follow an $\mathrm{MA}(m-1)$ process as a result. For example, the 1-year inflation rate is constructed by comparing changes in the price level between periods $t$ and $t+12$, $t+1$ and $t+13$, and so on. For this reason, we choose to use the well-documented Newey and West (1987) covariance matrix to obtain consistent estimates of the standard errors.

Almost all parameters are statistically significant, and we also notice that the best fit occurs when using information in the middle of the yield curve. In particular, the difference between 5-year and 1-year bond rates appears to contain the most information about inflation changes in the United States. This finding is consistent with Mishkin (1990b), whose sample covers the period 1953 to 1987 . Furthermore, the slope parameters are largely positive, with the exception of yield spreads that are constructed using information exclusively at the short or long ends of the yield curves. At the short end, we find that the yield spread contains very little information about

2. Elliott and Stock (1994) have noted that pretesting for unit roots in models with persistent regressors may not be valid, and thus caution should be exercised when conducting inference in our models. We thank a referee for pointing this out.

3. Unit root and long-memory tests are available from the author upon request. 
inflation changes, as shown by the small $\mathrm{R}^{2}$ statistics. This result is similar to that of Mishkin (1990a), who finds no useful information at the short end of the yield curve.

\section{Threshold Models}

\subsection{Motivation}

In this section, we estimate a model that allows for asymmetry in the form of a threshold effect of the yield spread on inflation changes. Our motivation stems from the possible asymmetric effects of monetary policy on the economy, since some yield spreads may be capturing the monetary policy stance. In general, monetary policy is conducted through money market intervention that impacts short-term interest rates, such as the federal funds rate. When such a rate changes, other rates respond in succession, with shorter rates being more responsive. The correlation between longer rates with shorter rates diminishes along the maturity spectrum as the term increases; for example, see Gong and Remolona (1997). At the longest horizons, monetary policy can influence rates only through its influence on inflation expectations; Mehra (1996) provides some recent evidence to this effect.

Bernanke and Blinder (1992) note that the spread between long-term bonds and the federal funds rate captures a great deal of information regarding the monetary policy stance. Consistent with Blinder (1998), the long-term rate may in fact be a proxy for the equilibrium, or policy-neutral, short-term rate. When the short-term rate is below neutral, the inflation rate should rise; when it is above, inflation should fall. A constant inflation rate would prevail only when the short-term rate is equal to the neutral rate. If the long-term rate is indeed a proxy for the neutral rate, then it should follow that yield spreads between any long-term and short-term securities would capture information regarding the monetary policy stance.

If we assume that "long" applies to any security with a maturity of two, five, or 10 years, and "short" to securities of three, six, and 12 months, then we can view any such long-short yield spread as a rough measure of monetary policy. More importantly, the levels of such spreads can be influenced to a certain extent by policy actions, because short-term rates react more quickly to policy actions than long-term rates. Thus, the policy-relevant $(m, n)$ horizons for the United States correspond to the first nine rows of Table 1: $(24,3),(60,3),(120,3),(24,6),(60,6),(120,6),(24,12)$, $(60,12)$, and $(120,12)$. For Canada, owing to the lack of a 6-month series, the policy-relevant horizons are the first six rows of Table 2. 
For some yield spreads, it is difficult to attach any policy interpretation, as for those spreads between securities with maturities of one year or less and between securities with maturities of greater than two years. In the former case, the central bank would have considerable influence on both rates; therefore, any policy action would be reflected by movements in both short-term rates, with changes in the spread being small. By contrast, the central bank would have little influence on either rate for spreads constructed using information at the longer end of the yield curve. In both instances, the interest rates embody similar expectations; the information content for future inflation that one can expect to extract from these spreads would therefore be lower than for the spreads on interest rates of more varied maturities. Nevertheless, we conduct tests for asymmetries at these horizons as well, to determine whether the information extracted from yield spreads can be improved. The non-policy horizons for the United States at the short end of the yield curve are $(6,3),(12,3)$, and $(12,6)$, while the non-policy horizons at the long end are $(60,24)$, $(120,24)$, and $(120,60)$. For Canada, the non-policy horizons are $(12,3),(60,24),(120,24)$, and $(120,60)$.

\subsection{Testing methodology}

To test for the asymmetric effects of the yield spread on inflation changes, we require a model that allows for regime changes that can be triggered by the level of the yield spread. If the spread is a gauge of policy, with the long rate representing the policy-neutral rate, then inversions of the yield curve would be roughly considered tight policy regimes, and upward-sloping yield curves expansionary regimes.

To improve the precision of our threshold test, we propose to search over possible threshold values to maximize the probability of uncovering any asymmetries in the relationship, should they indeed exist. Thus, we define "asymmetry" as any non-constant effect of the yield spread on inflation changes. This definition is less restrictive than those used in most previous work concerning asymmetries in monetary policy.

Andrews (1993), however, notes that searching over a grid invalidates standard statistical inference, and therefore we cannot test the significance of the thresholds with the usual $t$-statistics. Fortunately, Hansen (1996) proposes a method to circumvent this issue by allowing us to conduct inference using an estimate of the asymptotic distribution (obtained through bootstrapping) of the test statistic, from which $p$-values are obtained. In our work, we use 2000 bootstrap replications to simulate the asymptotic distribution.

The threshold model, which can be viewed as the alternative hypothesis to the linear relationship (11), can be specified as 


$$
\begin{gathered}
\pi_{t}^{m}-\pi_{t}^{n}=\alpha_{m, n}^{1}+\beta_{m, n}^{1}\left(R_{t}^{m}-R_{t}^{n}\right)+\eta_{m, n} \text { for }\left(R_{t}^{m}-R_{t}^{n}\right) \leq \tau, \text { and } \\
\pi_{t}^{m}-\pi_{t}^{n}=\alpha_{m, n}^{2}+\beta_{m, n}^{2}\left(R_{t}^{m}-R_{t}^{n}\right)+\eta_{m, n} \text { for }\left(R_{t}^{m}-R_{t}^{n}\right)>\tau,
\end{gathered}
$$

where $\tau$ represents the level of the yield spread that triggers a regime change. For each potential threshold value, $\tau$, we compute an LM statistic to test the null hypothesis of linearity. To reduce the impact of outliers, which may bias the test results, we follow the suggestion of Andrews (1993) for search procedures of this type, by trimming the grid by 15 per cent at either end, thereby eliminating the highest and lowest yield-spread values. ${ }^{4}$

To estimate the parameters in the threshold model (12) to (13), we follow Hansen (2000), who estimates the asymptotic distribution of the threshold parameter's least-squares estimator (LSE). Again, because the threshold parameter, $\tau$, is treated as unknown, the asymptotic distribution of its LSE is non-standard. To understand how the parameters are estimated, as with Hansen (2000) we introduce an indicator function, $d$, and can rewrite (12) to (13) as a single equation:

$$
\pi_{t}^{m}-\pi_{t}^{n}=\alpha_{m, n}^{2}+\beta_{m, n}^{2}\left(R_{t}^{m}-R_{t}^{n}\right)+\delta_{m, n} d+\gamma_{m, n} d\left(R_{t}^{m}-R_{t}^{n}\right)+\eta_{m, n}
$$

where

$$
\begin{aligned}
& d=\left\{\begin{array}{c}
1 \text { for }\left(R_{t}^{m}-R_{t}^{n}\right) \leq \tau \\
0 \text { for }\left(R_{t}^{m}-R_{t}^{n}\right)>\tau
\end{array},\right. \\
& \alpha_{m, n}^{2}+\delta_{m, n}=\alpha_{m, n}^{1}, \text { and } \\
& \beta_{m, n}^{2}+\gamma_{m, n}=\beta_{m, n}^{1} .
\end{aligned}
$$

By assuming that $\hat{\tau}$ is bounded by the largest and smallest values of the yield spread, we can estimate the parameters in (14) by least squares conditional on a given value for $\hat{\tau}$. By iterating through the possible values of $\hat{\tau}$ in the range of available yield spread values, we select the $\hat{\tau}$ that minimizes the sum of squared residuals in (14), and therefore are not constrained by the trimming used to conduct inference on the existence of a threshold.

4. Because the amount of trimming used for the test is somewhat arbitrary, we also experimented with 5, 10 , and 20 per cent trimming. The conclusions regarding the existence of threshold effects were not altered. 


\section{$3.3 \quad$ U.S. estimates}

The results of estimating the threshold model (14) using $\tau=\hat{\tau}$, where $\hat{\tau}$ is the threshold that minimizes the sum of squared errors for each $(m, n)$ combination, are shown in Table 3 for the policy-relevant horizons, as are the $p$-values for the significance of the thresholds. Three of the results will be described below.

First, for each $(m, n)$ combination in the table, we obtain $p$-values of 0.00 for each test and thus can reject the hypothesis of no threshold effect at any usual significance level. This is evidence of significant non-linearities between the yield spread and inflation changes.

Second, we find that, for six of the nine horizons in Table 3, the estimated thresholds are negative, which indicates that the yield spread has a stronger impact on inflation when the yield curve is inverted. Because such episodes are often associated with a tightening of monetary policy, the finding of a significant threshold effect may be related to an asymmetry in the effect of monetary policy on inflation.

Third, although there are relatively fewer observations below the estimated thresholds than above, it appears that these observations account for almost all of the yield spread's explanatory power for inflation. For example, consider the best indicator of monetary policy stance-namely, the difference between the longest and shortest interest rates $\left(R^{120}-R^{3}\right)$ — which is a good estimate of the yield curve's slope. Below the threshold of -0.46 , we find that a 100 -basis-point drop in the yield spread will cause the difference in the 10-year and 3-month inflation rates to fall by 1.76 per cent. Alternatively, above this threshold the same change in the yield spread will have virtually no impact on the change in inflation. Thus, a standard upward-sloping yield curve can be seen to have no useful information for inflation, a finding that is in stark contrast to the linear-model results in Table 1, Mishkin (1990b), and Frankel and Lown (1994).

The negative values of several thresholds may indicate that the form of asymmetry described by Friedman (1968) is perhaps most evident when policy tightens substantially, since only 10 per cent of the total number of observations are located below the thresholds, and thus represent more extreme and unusual episodes. A mild inversion of the yield curve would not be sufficient to induce notably large drops in consumption, investment, and hence inflation. On the other hand, a substantially tighter policy, resulting in notably higher short-term rates relative to long-term rates, would cause more dramatic reductions in aggregate demand and inflation.

In practice, however, if central bankers decided to set policy by targeting the yield spread in a manner consistent with our estimated threshold relationship, the Lucas critique could apply. 
Specifically, if in the future they followed a rule whereby tight policy had a stronger impact on inflation, then the estimated parameters in (14) would likely not be stable. As a result, equation (14) would be of greater use to forecasters who specialize in extracting information from financial variables, rather than serve as a rigid rule for policy-makers to follow.

Table 4 lists the results for other regions of the yield curve, described as non-policy horizons because they consider differences at either the short or longer ends of the yield curve. For the nonpolicy horizons at the short end of the yield curve, we find that little information can be extracted from interest rates. We detect only a threshold for the difference between 12-month and 3-month interest rates, but even here the information that is extracted is marginal. Thus our findings corroborate those by Mishkin (1990a), in that little information can be extracted from the short end of the yield curve.

At the longer end of the yield curve, however, there is again some useful additional information to be gained from threshold models. For the 5-year less the 2-year horizon ( $m=60, n=24)$, the threshold is estimated at 0.376 . Below this value, the slope parameter equals 2.280 , but above the threshold the slope is -0.361 . In other words, the predicted impact of such a yield spread on inflation changes results not only in different magnitudes, but also in different directions about the movements of the 5-year inflation rate relative to the 2-year inflation rate. Such information can be invaluable to forward-looking policy-makers, and cannot be extracted from linear models, which we found in Table 1 had estimated a slope of 1.224, representing a weighted average of the two threshold model slopes. Because these particular yield spreads cannot be directly controlled through policy, and hence cannot be affected by changes in the direction of policy, the Lucas critique would not apply.

As we have stated, the finding of threshold effects between several yield spreads-some of which may be construed as capturing monetary policy effects - and inflation changes may be linked to the literature on asymmetries in monetary policy. Previous authors have detected asymmetries between monetary policy variables and output growth. Because asymmetries appear to exist between interest rates and economic activity, and because inflation can respond to excess aggregate demand through a Phillips curve relationship, it follows that asymmetries between interest rates and inflation would be consistent under an asymmetric interest rate channel of the monetary policy transmission mechanism.

\subsection{Canadian estimates}

Table 5 lists the parameter estimates for all the Canadian threshold models. Relative to the U.S. results, there are three noteworthy features. 
First, the evidence in favour of threshold effects is less evident overall in the Canadian data. Of the ten tests performed, a significant threshold is detected in only seven cases. In those seven cases, $p$ values are not necessarily equal to 0.00 , as they were in many instances for the United States.

Second, the estimated thresholds are somewhat higher in the Canadian data, with the result that the proportion of data in the extreme regime is in the range of 20 to 30 per cent, compared with 10 per cent in many of the U.S. models.

Third, the estimated parameters are often more significant above the threshold than below, with the result that the estimated regressions fit the data better in Regime 2 than in Regime 1. For example, consider again the case of the best indicator of monetary policy stance: the difference between the longest and shortest interest rates $\left(R^{120}-R^{3}\right)$. The threshold is estimated at a relatively high value of 1.99 , which is usually associated with periods of notable monetary stimulus. Below this value, a 100-basis-point increase in the yield spread would result in a 0.71 per cent increase in the long-run inflation rate relative to the short-run inflation rate. Above this threshold, however, the same degree of marginal monetary stimulus would cause long-run inflation to rise by more than 4 per cent relative to short-run inflation.

These differences relative to the U.S. results can be partly accounted for by the fact that the Canadian sample begins in 1972 and captures many high-inflation years relative to the overall sample size. Alternatively, the data may reveal more fundamental differences between the transmission mechanisms of Canadian and U.S. monetary policies. In particular, Canada being a small open economy heavily reliant on trade, Canadian interest rates incorporate risk premia to account for exchange rate fluctuations. As a result, the omission of exchange rates in (11) may partially explain the observed differences in asymmetry.

\section{Conclusion}

This paper has presented a standard model, relying on the foundations of the Fisher equation, to link changes in inflation to interest rate yield spreads. Positing that yield spreads may have asymmetric effects on inflation changes, we estimated threshold models for various forecasting horizons. This exercise has proved useful for exploiting the information content of interest rate yield spreads, and also for testing for possible asymmetric effects of monetary policy on future inflation.

For the United States, we found that, for policy-relevant horizons, the relationship between longshort yield spreads and inflation changes is more pronounced when the spread is below some threshold, usually below 0.00 . The consequence of asymmetry at such horizons is that the 
marginal benefits of a tightening of monetary policy, in terms of a reduction in inflation, would be larger when monetary policy is already tight. This finding is consistent with earlier studies that have found the effects of monetary policy on output to be asymmetric. If policy-makers targeted the yield spread in a manner consistent with these findings, however, the Lucas critique would apply. For this reason, these results should be of most value to forecasters who specialize in extracting information from financial variables.

For non-policy horizons, such as those relating to either the short or long end of the yield curve, we have found that there is little information content at the short end, and that both the magnitudes and directions of long-term inflation forecasts are affected by thresholds. As a result, at long horizons inflation forecasters should be vigilant when extracting information from longterm yield spreads, as both the magnitude and direction of long-term inflation rates are dependent upon the level of yield spreads.

For Canada, the evidence of asymmetry is weaker, and for the asymmetries that we did uncover we found that the pattern is markedly different than for the U.S. asymmetries. Such results may be partly explained by different sample sizes, but may possibly reveal fundamental differences between U.S. and Canadian monetary policies. In particular, the absence of exchange rates in our model may result in biases in our estimated parameters. The incorporation of exchange rates in such an analysis requires further investigation.

Because we have detected some evidence of non-linearities between yield spreads and inflation changes through a simple two-regime threshold model, in future work it would be useful to compare linear and non-linear models in an out-of-sample forecasting exercise. The set of nonlinear models can include the threshold model described here, in addition to general non-linear models, such as non-parametric models and neural networks. 


\section{References}

Andrews, D.W.K. 1993. “Tests for Parameter Instability and Structural Change with Unknown Change Point.” Econometrica 55: 1465-71.

Bernanke, B.S. and A. Blinder. 1992. "The Federal Funds Rate and the Channels of Monetary Transmission." American Economic Review 82: 901-21.

Blinder, A. 1998. Central Banking in Theory and Practice. Cambridge: MIT Press.

Bliss, R.R. 1997. “Testing Term Structure Estimation Methods.” Advances in Futures and Options Research 9: 197-231.

Day, J. and R. Lange. 1997. "The Structure of Interest Rates in Canada: Information Content About Medium-Term Inflation.” Bank of Canada Working Paper No. 97-10.

Diebold, F.X. and G.D. Rudebusch. 1991. "On the Power of Dickey Fuller Test Against Fractional Alternatives." Economics Letters 35: 155-60.

Duffee, G.R. 2002. "Term Premia and Interest Rate Forecasts in Affine Models." Journal of Finance 57: 405-43.

Elliott, G. and J.H. Stock. 1994. "Inference in Time Series Regression when the Order of Integration of a Regressor is Unknown.” Econometric Theory 10: 672-700.

Frankel, J.A. and C.S. Lown. 1994. "An Indicator of Future Inflation Extracted from the Steepness of the Interest Rate Yield Curve Along Its Entire Length." Quarterly Journal of Economics 109: 517-30.

Friedman, M. 1968. “The Role of Monetary Policy.” American Economic Review 58: 1-17.

Galbraith, J.W. and G. Tkacz. 2000. "Testing for Asymmetry in the Link Between the Yield Spread and Output in the G-7 Countries." Journal of International Money and Finance 19: $657-72$.

Gong, F.F. and E. Remolona. 1997. A Three-Factor Econometric Model of the U.S. Term Structure. Staff Report Number 19, Federal Reserve Bank of New York.

Hansen, B.E. 1996. "Inference When a Nuisance Parameter Is Not Identified Under the Null Hypothesis." Econometrica 64: 413-30.

—. 2000. "Sample Splitting and Threshold Estimation.” Econometrica 68: 575-603.

Johnson, M. and R. Keleher. 1996. Monetary Policy: A Market Price Approach. Westport, CT: Quorum Books.

Karras, G. 1996. "Why Are the Effects of Money-Supply Shocks Asymmetric? Convex Aggregate Supply or 'Pushing on a String'?” Journal of Macroeconomics 18: 605-19.

Karras, G. and H.H. Stokes. 1999. "Why Are the Effects of Money-Supply Shocks Asymmetric? Evidence from Prices, Consumption and Investment." Journal of Macroeconomics 21: 713-27. 
Laurent, R.D. 1988. “An Interest-Based Indicator of Monetary Policy.” Federal Reserve Bank of Chicago Economic Perspectives 12: 3-14.

- 1989. "Testing the 'Spread'." Federal Reserve Bank of Chicago Economic Perspectives 13: $22-34$.

Lo, A.W. 1991. “Long Term Memory in Stock Prices.” Econometrica 59: 1279-1313.

McCulloch, J.H. and H. Kwon. 1993. “U.S. Term Structure Data, 1947-1991.” Working Paper No. 93-6, Economics Department, Ohio State University.

Mehra, Y.P. 1996. "Monetary Policy and Long-Term Interest Rates.” Federal Reserve Bank of Richmond Economic Quarterly 82(3): 27-49.

Mishkin, F.S. 1990a. "What Does the Term Structure Tell Us About Future Inflation?” Journal of Monetary Economics 25: 77-95.

- 1990b. "The Information in the Longer-Maturity Term Structure About Future Inflation." Quarterly Journal of Economics 105: 815-28.

—. 1991. "A Multi-Country Study of the Information in the Shorter Maturity Term Structure About Future Inflation.” Journal of International Money and Finance 10: 2-22.

Morgan, D.P. 1993. "Asymmetric Effects of Monetary Policy." Federal Reserve Bank of Kansas City Economic Review 78: 21-33.

Newey, W.K. and K.D. West. 1987. “A Simple Positive Semi-Definite Heteroskedasticity and Autocorrelation-Consistent Covariance Matrix." Econometrica 55: 703-8.

Rhee, W. and R.W. Rich. 1995. "Inflation and the Asymmetric Effects of Money on Output Fluctuations." Journal of Macroeconomics 17: 683-702.

Tkacz, G. 2000. "Non-Parametric and Neural Network Models of Inflation Changes.” Bank of Canada Working Paper No. 2000-7. 
Table 1: Linear Models, United States

\begin{tabular}{|c|c|c|c|c|}
\hline $\begin{array}{c}m, n \\
\text { (months) }\end{array}$ & $\begin{array}{l}\text { Obser- } \\
\text { vations }\end{array}$ & Constant & Slope & $\mathrm{R}^{2}$ \\
\hline 24,3 & 540 & $\begin{array}{l}-0.630 \\
(0.125)\end{array}$ & $\begin{array}{c}0.939 \\
(0.129)\end{array}$ & 0.104 \\
\hline 60,3 & 504 & $\begin{array}{l}-1.055 \\
(0.163)\end{array}$ & $\begin{array}{c}1.179 \\
(0.115)\end{array}$ & 0.229 \\
\hline 120,3 & 444 & $\begin{array}{c}-0.806 \\
(0.218)\end{array}$ & $\begin{array}{c}1.058 \\
(0.134)\end{array}$ & 0.177 \\
\hline 24,6 & 540 & $\begin{array}{c}-0.428 \\
(0.078)\end{array}$ & $\begin{array}{c}0.983 \\
(0.114)\end{array}$ & 0.139 \\
\hline 60,6 & 504 & $\begin{array}{c}-0.774 \\
(0.122)\end{array}$ & $\begin{array}{c}1.170 \\
(0.107)\end{array}$ & 0.260 \\
\hline 120,6 & 444 & $\begin{array}{c}-0.533 \\
(0.177)\end{array}$ & $\begin{array}{c}1.032 \\
(0.127)\end{array}$ & 0.181 \\
\hline 24,12 & 540 & $\begin{array}{c}-0.266 \\
(0.043)\end{array}$ & $\begin{array}{c}1.153 \\
(0.107)\end{array}$ & 0.187 \\
\hline 60,12 & 504 & $\begin{array}{c}-0.601 \\
(0.097)\end{array}$ & $\begin{array}{c}1.267 \\
(0.113)\end{array}$ & 0.274 \\
\hline 120,12 & 444 & $\begin{array}{c}-0.373 \\
(0.155)\end{array}$ & $\begin{array}{c}1.078 \\
(0.132)\end{array}$ & 0.167 \\
\hline 6,3 & 558 & $\begin{array}{c}-0.011 \\
(0.077)\end{array}$ & $\begin{array}{c}0.057 \\
(0.261)\end{array}$ & 0.000 \\
\hline 12,3 & 552 & $\begin{array}{c}-0.194 \\
(0.101)\end{array}$ & $\begin{array}{c}0.443 \\
(0.167)\end{array}$ & 0.017 \\
\hline 12,6 & 552 & $\begin{array}{l}-0.079 \\
(0.054)\end{array}$ & $\begin{array}{c}0.384 \\
(0.182)\end{array}$ & 0.012 \\
\hline 60,24 & 504 & $\begin{array}{l}-0.322 \\
(0.084)\end{array}$ & $\begin{array}{c}1.224 \\
(0.147)\end{array}$ & 0.157 \\
\hline 120,24 & 444 & $\begin{array}{c}-0.054 \\
(0.144)\end{array}$ & $\begin{array}{c}0.677 \\
(0.174)\end{array}$ & 0.042 \\
\hline 120,60 & 444 & $\begin{array}{c}0.285 \\
(0.058)\end{array}$ & $\begin{array}{l}-1.293 \\
(0.202)\end{array}$ & 0.082 \\
\hline
\end{tabular}

Note: Consistent standard errors are in parentheses. 
Table 2: Linear Models, Canada

\begin{tabular}{|c|c|c|c|c|}
\hline $\begin{array}{c}m, n \\
\text { (months) }\end{array}$ & $\begin{array}{l}\text { Obser- } \\
\text { vations }\end{array}$ & Constant & Slope & $\mathrm{R}^{2}$ \\
\hline 24,3 & 342 & $\begin{array}{l}-0.244 \\
(0.115)\end{array}$ & $\begin{array}{c}0.507 \\
(0.108)\end{array}$ & 0.066 \\
\hline 60,3 & 306 & $\begin{array}{l}-1.037 \\
(0.151)\end{array}$ & $\begin{array}{c}0.754 \\
(0.082)\end{array}$ & 0.175 \\
\hline 120,3 & 246 & $\begin{array}{l}-2.079 \\
(0.153)\end{array}$ & $\begin{array}{c}0.836 \\
(0.083)\end{array}$ & 0.254 \\
\hline 24,12 & 342 & $\begin{array}{c}-0.200 \\
(0.060)\end{array}$ & $\begin{array}{c}0.812 \\
(0.167)\end{array}$ & 0.083 \\
\hline 60,12 & 306 & $\begin{array}{l}-1.145 \\
(0.100)\end{array}$ & $\begin{array}{c}1.322 \\
(0.090)\end{array}$ & 0.317 \\
\hline 120,12 & 246 & $\begin{array}{l}-2.228 \\
(0.104)\end{array}$ & $\begin{array}{c}1.256 \\
(0.086)\end{array}$ & 0.408 \\
\hline 12,3 & 354 & $\begin{array}{c}-0.079 \\
(0.091)\end{array}$ & $\begin{array}{c}0.206 \\
(0.103)\end{array}$ & 0.010 \\
\hline 60,24 & 306 & $\begin{array}{c}-0.916 \\
(0.076)\end{array}$ & $\begin{array}{c}1.459 \\
(0.115)\end{array}$ & 0.284 \\
\hline 120,24 & 246 & $\begin{array}{l}-2.027 \\
(0.102)\end{array}$ & $\begin{array}{l}1.208 \\
(0.100)\end{array}$ & 0.349 \\
\hline 120,60 & 246 & $\begin{array}{l}-0.975 \\
(0.072)\end{array}$ & $\begin{array}{c}0.530 \\
(0.136)\end{array}$ & 0.045 \\
\hline
\end{tabular}

Note: Consistent standard errors are in parentheses. 
Table 3: Threshold Models for Policy-Relevant Horizons, United States

\begin{tabular}{|c|c|c|c|c|c|c|c|c|}
\hline $\begin{array}{c}m, n \\
\text { (months) }\end{array}$ & $\begin{array}{c}\text { sup- } L M \\
{[p \text {-value }]}\end{array}$ & $\hat{\tau}$ & Regime & $\begin{array}{l}\text { Obser- } \\
\text { vations }\end{array}$ & Constant & Slope & $\mathrm{R}^{2}$ & $\begin{array}{l}\text { Residual } \\
\text { variance }\end{array}$ \\
\hline \multirow[t]{2}{*}{24,3} & \multirow[t]{2}{*}{$\begin{array}{l}31.62 \\
{[0.00]}\end{array}$} & \multirow[t]{2}{*}{-0.001} & 1 & 54 & \multirow{2}{*}{$\begin{array}{c}-1.405 \\
(0.350) \\
0.039 \\
(0.147)\end{array}$} & \multirow{2}{*}{$\begin{array}{c}1.534 \\
(0.452) \\
0.271 \\
(0.148)\end{array}$} & 0.149 & 3.672 \\
\hline & & & 2 & 486 & & & 0.007 & 3.093 \\
\hline \multirow[t]{2}{*}{60,3} & \multirow[t]{2}{*}{$\begin{array}{l}52.64 \\
{[0.00]}\end{array}$} & \multirow[t]{2}{*}{-0.538} & 1 & 39 & \multirow{2}{*}{$\begin{array}{l}-3.278 \\
(0.552) \\
-0.026 \\
(0.166)\end{array}$} & \multirow{2}{*}{$\begin{array}{c}1.369 \\
(0.490) \\
0.476 \\
(0.111)\end{array}$} & 0.167 & 4.100 \\
\hline & & & 2 & 465 & & & 0.036 & 4.262 \\
\hline \multirow[t]{2}{*}{120,3} & \multirow[t]{2}{*}{$\begin{array}{l}62.15 \\
{[0.00]}\end{array}$} & \multirow[t]{2}{*}{-0.456} & 1 & 45 & \multirow{2}{*}{$\begin{array}{c}-2.672 \\
(0.778) \\
0.805 \\
(0.225)\end{array}$} & \multirow{2}{*}{$\begin{array}{c}1.758 \\
(0.500) \\
0.078 \\
(0.132)\end{array}$} & 0.169 & 8.877 \\
\hline & & & 2 & 399 & & & 0.001 & 5.533 \\
\hline \multirow[t]{2}{*}{24,6} & \multirow[t]{2}{*}{$\begin{array}{l}42.63 \\
{[0.00]}\end{array}$} & \multirow[t]{2}{*}{0.654} & 1 & 356 & \multirow{2}{*}{$\begin{array}{c}-0.419 \\
(0.073) \\
0.419 \\
(0.435)\end{array}$} & \multirow{2}{*}{$\begin{array}{c}1.917 \\
(0.174) \\
-0.155 \\
(0.425)\end{array}$} & 0.281 & 1.713 \\
\hline & & & 2 & 184 & & & 0.001 & 1.539 \\
\hline \multirow[t]{2}{*}{60,6} & \multirow[t]{2}{*}{$\begin{array}{l}61.69 \\
{[0.00]}\end{array}$} & \multirow[t]{2}{*}{-0.601} & 1 & 44 & \multirow{2}{*}{$\begin{array}{c}-2.919 \\
(0.730) \\
0.084 \\
(0.126)\end{array}$} & \multirow{2}{*}{$\begin{array}{c}1.037 \\
(0.588) \\
0.461 \\
(0.105)\end{array}$} & 0.110 & 3.149 \\
\hline & & & 2 & 460 & & & 0.039 & 3.013 \\
\hline \multirow[t]{2}{*}{120,6} & \multirow[t]{2}{*}{$\begin{array}{l}71.67 \\
{[0.00]}\end{array}$} & \multirow[t]{2}{*}{-0.624} & 1 & 45 & \multirow{2}{*}{$\begin{array}{c}-2.906 \\
(1.092) \\
0.704 \\
(0.181)\end{array}$} & \multirow{2}{*}{$\begin{array}{c}1.066 \\
(0.617) \\
0.125 \\
(0.126)\end{array}$} & 0.052 & 9.890 \\
\hline & & & 2 & 399 & & & 0.003 & 4.358 \\
\hline \multirow[t]{2}{*}{24,12} & \multirow[t]{2}{*}{$\begin{array}{l}70.35 \\
{[0.00]}\end{array}$} & \multirow[t]{2}{*}{0.290} & 1 & 313 & \multirow{2}{*}{$\begin{array}{c}-0.250 \\
(0.042) \\
0.955 \\
(0.174)\end{array}$} & \multirow{2}{*}{$\begin{array}{c}2.114 \\
(0.165) \\
-1.156 \\
(0.292)\end{array}$} & 0.346 & 0.564 \\
\hline & & & 2 & 227 & & & 0.057 & 0.639 \\
\hline 60,12 & $\begin{array}{l}67.62 \\
{[0.00]}\end{array}$ & 0.646 & 1 & 280 & $\begin{array}{l}-0.580 \\
(0.087)\end{array}$ & $\begin{array}{c}2.401 \\
(0.196)\end{array}$ & 0.438 & 2.139 \\
\hline & & & 2 & 224 & $\begin{array}{l}1.508 \\
(0.232)\end{array}$ & $\begin{array}{l}-0.463 \\
(0.161)\end{array}$ & 0.020 & 2.276 \\
\hline 120,12 & $\begin{array}{l}71.12 \\
{[0.00]}\end{array}$ & -0.639 & 1 & 45 & $\begin{array}{c}-2.363 \\
(0.995)\end{array}$ & $\begin{array}{c}1.035 \\
(0.553)\end{array}$ & 0.034 & 9.120 \\
\hline & & & 2 & 399 & $\begin{array}{c}0.530 \\
(0.171)\end{array}$ & $\begin{array}{c}0.245 \\
(0.145)\end{array}$ & 0.008 & 3.909 \\
\hline
\end{tabular}

Notes: sup-LM is the heteroscedasticity-corrected test statistic of Hansen (1996) to test for the hypothesis of no threshold against the alternative of a threshold. The $p$-values for this test were computed using 2000 bootstrap replications. $\hat{\tau}$ is the estimated yield-spread value that maximizes the likelihood of detecting a threshold effect.

Regime 1 is defined as periods for which $\left(R_{t}^{m}-R_{t}^{n}\right) \leq \hat{\tau}$, and Regime 2 represents periods for which $\left(R_{t}^{m}-R_{t}^{n}\right)>\hat{\tau}$. Consistent standard errors are in parentheses. 
Table 4: Threshold Models for Non-Policy Horizons, United States

\begin{tabular}{|c|c|c|c|c|c|c|c|c|}
\hline $\begin{array}{c}m, n \\
\text { (months) }\end{array}$ & $\begin{array}{c}\text { sup- } L M \\
{[p \text {-value }]}\end{array}$ & $\hat{\tau}$ & Regime & $\begin{array}{l}\text { Obser- } \\
\text { vations }\end{array}$ & Constant & Slope & $\mathrm{R}^{2}$ & $\begin{array}{l}\text { Residual } \\
\text { variance }\end{array}$ \\
\hline 6,3 & $\begin{array}{c}4.14 \\
{[0.64]}\end{array}$ & \multicolumn{7}{|c|}{ No significant threshold } \\
\hline \multirow[t]{2}{*}{12,3} & $\begin{array}{l}12.14 \\
{[0.02]}\end{array}$ & -0.226 & 1 & & $\begin{array}{l}-1.555 \\
(0.936)\end{array}$ & $\begin{array}{c}0.382 \\
(1.088)\end{array}$ & 0.005 & 4.452 \\
\hline & & & 2 & 535 & $\begin{array}{c}0.005 \\
(0.100)\end{array}$ & $\begin{array}{c}0.113 \\
(0.171)\end{array}$ & 0.001 & 1.937 \\
\hline 12,6 & $\begin{array}{c}7.57 \\
{[0.18]}\end{array}$ & \multicolumn{7}{|c|}{ No significant threshold } \\
\hline \multirow[t]{2}{*}{60,24} & $\begin{array}{l}35.64 \\
{[0.00]}\end{array}$ & 0.376 & 1 & 284 & $\begin{array}{c}-0.348 \\
(0.083)\end{array}$ & $\begin{array}{c}2.280 \\
(0.311)\end{array}$ & 0.197 & 1.960 \\
\hline & & & 2 & 220 & $\begin{array}{c}0.867 \\
(0.177)\end{array}$ & $\begin{array}{l}-0.361 \\
(0.197)\end{array}$ & 0.010 & 1.221 \\
\hline \multirow[t]{2}{*}{120,24} & $\begin{array}{l}31.59 \\
{[0.00]}\end{array}$ & -0.570 & 1 & 33 & $\begin{array}{c}-2.685 \\
(1.222)\end{array}$ & $\begin{array}{c}-0.483 \\
(1.027)\end{array}$ & 0.004 & 10.24 \\
\hline & & & 2 & 411 & $\begin{array}{c}0.382 \\
(0.154)\end{array}$ & $\begin{array}{c}0.086 \\
(0.185)\end{array}$ & 0.001 & 3.682 \\
\hline \multirow[t]{2}{*}{120,60} & $\begin{array}{l}22.59 \\
{[0.00]}\end{array}$ & 0.351 & 1 & 347 & $\begin{array}{c}0.321 \\
(0.057)\end{array}$ & $\begin{array}{c}-0.262 \\
(0.222)\end{array}$ & 0.003 & 1.180 \\
\hline & & & 2 & 97 & $\begin{array}{c}0.585 \\
(0.629)\end{array}$ & $\begin{array}{l}-2.543 \\
(1.165)\end{array}$ & 0.047 & 1.695 \\
\hline
\end{tabular}

Notes: sup-LM is the heteroscedasticity-corrected statistic of Hansen (1996) used to test for the hypothesis of no threshold against the alternative of a threshold. The $p$-values for this test were computed using 2000 bootstrap replications. $\hat{\tau}$ is the estimated yield-spread value that maximizes the likelihood of detecting a threshold effect. Regime 1 is defined as periods for which $\left(R_{t}^{m}-R_{t}^{n}\right) \leq \hat{\tau}$, and Regime 2 represents periods for which $\left(R_{t}^{m}-R_{t}^{n}\right)>\hat{\tau}$. Consistent standard errors are in parentheses. 
Table 5: Threshold Models, Canada

\begin{tabular}{|c|c|c|c|c|c|c|c|c|}
\hline $\begin{array}{c}m, n \\
\text { (months) }\end{array}$ & $\begin{array}{c}\text { sup- } L M \\
{[p \text {-value }]}\end{array}$ & $\hat{\tau}$ & Regime & $\begin{array}{l}\text { Obser- } \\
\text { vations }\end{array}$ & Constant & Slope & $\mathrm{R}^{2}$ & $\begin{array}{l}\text { Residual } \\
\text { variance }\end{array}$ \\
\hline \multirow[t]{2}{*}{24,3} & \multirow[t]{2}{*}{$\begin{array}{c}13.04 \\
{[0.037]}\end{array}$} & \multirow[t]{2}{*}{2.360} & 1 & 338 & \multirow{2}{*}{$\begin{array}{c}-0.266 \\
(0.115) \\
59.98 \\
(20.32)\end{array}$} & \multirow{2}{*}{$\begin{array}{c}0.430 \\
(0.105) \\
-22.31 \\
(8.29)\end{array}$} & 0.048 & 4.224 \\
\hline & & & 2 & 4 & & & 0.610 & 4.550 \\
\hline 60,3 & $\begin{array}{c}8.12 \\
{[0.246]}\end{array}$ & \multicolumn{7}{|c|}{ No significant threshold } \\
\hline \multirow[t]{2}{*}{120,3} & \multirow[t]{2}{*}{$\begin{array}{c}24.23 \\
{[0.001]}\end{array}$} & \multirow[t]{2}{*}{1.990} & 1 & 205 & \multirow{2}{*}{$\begin{array}{l}-2.113 \\
(0.165) \\
-10.78 \\
(2.005)\end{array}$} & \multirow{2}{*}{$\begin{array}{c}0.712 \\
(0.096) \\
4.160 \\
(0.752)\end{array}$} & 0.164 & 5.668 \\
\hline & & & 2 & 41 & & & 0.546 & 4.017 \\
\hline \multirow[t]{2}{*}{24,12} & \multirow[t]{2}{*}{$\begin{array}{c}14.02 \\
{[0.022]}\end{array}$} & \multirow[t]{2}{*}{0.510} & 1 & 290 & \multirow{2}{*}{$\begin{array}{c}-0.197 \\
(0.059) \\
2.497 \\
(0.779)\end{array}$} & \multirow{2}{*}{$\begin{array}{c}0.975 \\
(0.236) \\
-3.263\end{array}$} & 0.082 & 0.968 \\
\hline & & & 2 & 52 & & & 0.161 & 0.826 \\
\hline \multirow[t]{2}{*}{60,12} & \multirow[t]{2}{*}{$\begin{array}{c}29.88 \\
{[0.000]}\end{array}$} & \multirow[t]{2}{*}{-0.164} & 1 & 58 & \multirow{2}{*}{$\begin{array}{c}-2.291 \\
(0.445) \\
-0.514 \\
(0.151)\end{array}$} & \multirow{2}{*}{$\begin{array}{c}0.739 \\
(0.421) \\
0.647 \\
(0.124)\end{array}$} & 0.052 & 2.006 \\
\hline & & & 2 & 248 & & & 0.052 & 2.399 \\
\hline \multirow[t]{2}{*}{120,12} & \multirow[t]{2}{*}{$\begin{array}{c}12.66 \\
{[0.043]}\end{array}$} & \multirow[t]{2}{*}{-0.626} & 1 & 41 & \multirow{2}{*}{$\begin{array}{c}-4.750 \\
(0.585) \\
-2.246 \\
(0.152)\end{array}$} & \multirow{2}{*}{$\begin{array}{c}-0.666 \\
(0.407) \\
1.306 \\
(0.133) \\
\end{array}$} & 0.048 & 1.653 \\
\hline & & & 2 & 205 & & & 0.257 & 2.337 \\
\hline 12,3 & $\begin{array}{c}6.858 \\
{[0.338]}\end{array}$ & \multicolumn{7}{|c|}{ No significant threshold } \\
\hline \multirow[t]{2}{*}{60,24} & \multirow[t]{2}{*}{$\begin{array}{c}49.69 \\
{[0.000]}\end{array}$} & \multirow[t]{2}{*}{-0.190} & 1 & 52 & $\begin{array}{l}-2.535 \\
(0.296)\end{array}$ & $\begin{array}{l}-0.477 \\
(0.468)\end{array}$ & 0.019 & 0.757 \\
\hline & & & 2 & 254 & $\begin{array}{l}-0.408 \\
(0.122)\end{array}$ & $\begin{array}{c}0.653 \\
(0.188)\end{array}$ & 0.041 & 1.254 \\
\hline \multirow[t]{2}{*}{120,24} & \multirow[t]{2}{*}{$\begin{array}{c}22.51 \\
{[0.001]}\end{array}$} & \multirow[t]{2}{*}{0.051} & 1 & 69 & \multirow{2}{*}{$\begin{array}{c}-3.002 \\
(0.299) \\
-1.695 \\
(0.160)\end{array}$} & \multirow{2}{*}{$\begin{array}{c}-0.119 \\
(0.426) \\
0.933 \\
(0.139)\end{array}$} & 0.001 & 2.004 \\
\hline & & & 2 & 177 & & & 0.130 & 1.178 \\
\hline 120,60 & $\begin{array}{c}9.879 \\
{[0.119]}\end{array}$ & & & & ignificant t & hold & & \\
\hline
\end{tabular}

Notes: sup-LM is the heteroscedasticity-corrected statistic of Hansen (1996) used to test for the hypothesis of no threshold against the alternative of a threshold. The $p$-values for this test were computed using 2000 bootstrap replications. $\hat{\tau}$ is the estimated yield-spread value that maximizes the likelihood of detecting a threshold effect. Regime 1 is defined as periods for which $\left(R_{t}^{m}-R_{t}^{n}\right) \leq \hat{\tau}$, and Regime 2 represents periods for which $\left(R_{t}^{m}-R_{t}^{n}\right)>\hat{\tau}$. Consistent standard errors are in parentheses. 


\section{Bank of Canada Working Papers \\ Documents de travail de la Banque du Canada}

Working papers are generally published in the language of the author, with an abstract in both official languages. Les documents de travail sont publiés généralement dans la langue utilisée par les auteurs; ils sont cependant précédés d'un résumé bilingue.

2002

2002-39 An Empirical Analysis of Dynamic Interrelationships Among Inflation, Inflation Uncertainty, Relative Price Dispersion, and Output Growth F. Vitek

2002-38 Oil-Price Shocks and Retail Energy Prices in Canada

M. Chacra

2002-37 Alternative Public Spending Rules and Output Volatility

J.-P. Lam and W. Scarth

2002-36 Une approche éclectique d'estimation du PIB potentiel américain

M.-A. Gosselin et R. Lalonde

2002-35 The Impact of Common Currencies on Financial Markets:

A Literature Review and Evidence from the Euro Area

L. Karlinger

2002-34 How Do Canadian Banks That Deal in Foreign

Exchange Hedge Their Exposure to Risk?

C. D'Souza

2002-33 Alternative Trading Systems: Does One

Shoe Fit All?

N. Audet, T. Gravelle, and J. Yang

2002-32 Labour Markets, Liquidity, and Monetary

Policy Regimes

D. Andolfatto, S. Hendry, and K. Moran

2002-31 Supply Shocks and Real Exchange Rate Dynamics:

Canadian Evidence

C. Gauthier and D. Tessier

2002-30 Inflation Expectations and Learning about

Monetary Policy

D. Andolfatto, S. Hendry, and K. Moran

2002-29 Exponentials, Polynomials, and Fourier Series:

More Yield Curve Modelling at the Bank of Canada

D.J. Bolder and S. Gusba

2002-28 Filtering for Current Analysis

S. van Norden

2002-27 Habit Formation and the Persistence

of Monetary Shocks

H. Bouakez, E. Cardia, and F.J. Ruge-Murcia

2002-26 Nominal Rigidity, Desired Markup Variations, and

Real Exchange Rate Persistence

H. Bouakez

2002-25 Nominal Rigidities and Monetary Policy in Canada

Since 1981

A. Dib

Copies and a complete list of working papers are available from:

Pour obtenir des exemplaires et une liste complète des documents de travail, prière de s'adresser à :

Publications Distribution, Bank of Canada

234 Wellington Street, Ottawa, Ontario K1A 0G9

E-mail: publications@bankofcanada.ca

Web site: http://www.bankofcanada.ca
Diffusion des publications, Banque du Canada

234, rue Wellington, Ottawa (Ontario) K1A 0G9 Adresse électronique : publications@ @anqueducanada.ca Site Web : http://www.banqueducanada.ca 